\title{
COMPARISON OF GROWTH RATES ESTIMATED BY OTOLITH READING OF Scorpaena porcus AND Scorpaena notata CAUGHT ON ARTIFICIAL AND NATURAL REEFS OF THE NORTHERN ADRIATIC SEA*
}

\author{
Giuseppe Scarcella**, Fabio Grati, Piero Polidori, Filippo Domenichetti and Luca Bolognini, Gianna Fabi \\ CNR - Istituto di Scienze Marine \\ (UOS di Ancona, Largo Fiera della Pesca, 60125 Ancona, Italy) \\ **Corresponding author: g.scarcella@ismar.cnr.it
}

\begin{abstract}
A B S TR ACT
Despite the high number of studies on fish assemblages associated with artificial reefs and offshore platforms, little information exists on the growth rates of fish living on artificial and natural substrates. Age and growth was determined throughout otolith reading on two commercial scorpionfishes (Scorpaena porcus and Scorpaena notata) caught in the surroundings of artificial structures (artificial reefs and gas platforms) and natural habitats. Von Bertalanffy growth parameters were calculated for each species separately for each site. Age of S. porcus and S. notata ranged from 0 to 8 years and from 0 to 16 years, respectively. Kimura test applied to Von Bertalanffy growth curves indicated that the individuals of both species inhabiting the artificial structures had higher growth parameters than those caught in the natural habitat. The presence of artificial habitats in the northern Adriatic Sea positively affects growth rates and growth performance of both species, likely for the greater prey availability in respect to the natural open sea.
\end{abstract}

\section{RESUMO}

Apesar do elevado número de estudos sobre as assembléias de peixes associadas a recifes artificiais e plataformas offshore, existe pouca informação sobre as taxas de crescimento dos peixes que vivem em substratos artificiais e naturais. A idade e crescimento foram determinados pela leitura de otólitos em dois peixes escorpião comerciais (Scorpaena porcus e Scorpaena notata) capturados nas imediações de estruturas artificiais (recifes artificiais e plataformas de gás) e habitats naturais. Parâmetros de crescimento de von Bertalanffy foram calculadoss separadamente para cada espécie e cada local. A idade de Scorpaena porcus e Scorpaena notata variou entre 0 e 8 anos e 0 e 16 anos, respectivamente. O teste Kimura aplicado às curvas de crescimento de Bertalanffy indicaram que os indivíduos das duas espécies que habitam as estruturas artificiais tinham parâmetros de crescimento mais elevados do que dos capturados no habitat natural. A presença de habitats artificiais no norte do Mar Adriático afeta positivamente as taxas de crescimento e o desempenho de crescimento de ambas as espécies, provavelmente pela maior disponibilidade de presas em relação ao mar aberto natural.

Descriptors: Scorpaena porcus, Scorpanea notata, Age and growth, Natural reefs, Artificial structures, Adriatic Sea.

Descritores: Scorpaena porcus, Scorpaena notata, Idade e crescimento, Recifes naturais, Estruturas artificiais, Mar Adriático.

\section{INTRODUCTION}

Scorpaena porcus and Scorpaena notata, commonly known as the black scorpionfish and the small red scorpionfish respectively, are distributed in the eastern Atlantic from the British Isles to Morocco and throughout the Mediterranean to the Black Sea. Both species are benthic, sedentary, of medium size

(*) Paper presented at the $9^{\text {th }}$ CARAH - International Conference on Artificial Reefs and Related Aquatic Habitats on 8-13 November, Curitiba, PR, Brazil.
(S. porcus up to $25 \mathrm{~cm} \mathrm{TL}$ and $S$. notata up to $20 \mathrm{~cm}$ TL) and commonly found among rocks and seagrass beds (FISHER et al., 1986).

$S$. porcus is a relatively slow-growing and short-lived fish, with a maximum life span of 11 years (BRADAI; BOUAIN, 1988; JARDAS; PALLAORO, 1992). Similarly, S. notata seems to grow slowly, but lives longer (16 years; SCARCELLA, 2010).

In the northern Adriatic Sea, S. porcus is commonly found in coastal waters, while $S$. notata is more abundant in deeper waters offshore. 
Despite their low commercial value, mainly due to their small size, $S$. porcus and $S$. notata play a crucial role in the hard-bottom ecosystems, representing two important reef-dwelling species attracted by artificial structures, such as artificial reefs and offshore gas platforms, and the rare rocky habitats of the Adriatic Sea (BOMBACE et al., 1994; FABI et al., 2004; CASELLATO; STEFANON, 2008). Many artificial reefs have been built in the last two decades throughout the Mediterranean in order to enhance local fish populations and to improve small scalefisheries as a consequence of fish attraction and/or production of new biomass (JENSEN, 2002). Indeed, several studies report high fish density, rapid colonization and high catch rates in areas where artificial reefs have been deployed (e.g. BOHNSACK; SUTHERLAND, 1985; CARR; HIXON, 1997). This is more evident in areas far from natural hard substrates, where artificial reefs can provide additional food and shelter to mitigate predation, as is the case of the Adriatic Sea (BOMBACE et al., 1990, 1994; FABI; FIORENTINI, 1994). Although offshore gas platforms have a different primary purpose, they act in a similar way to artificial reefs, concentrating fish throughout the water column (e.g. PAGE et al., 1999; STANLEY; WILSON, 2000; FABI et al., 2004).

Despite the great number of studies on the fish assemblages associated with artificial reefs and off-shore platforms, little information exists on the ecological performance of fish living on these substrates, in terms of differentiation in age and growth patterns from those of natural areas (LOVE et al., 2007).

In this study the differences in growth parameters between the scorpionfish populations sampled in their natural habitat (NR) and those living in artificial structures (AS) have been analyzed in terms of their age composition and growth rate estimated by otolith reading and by applying indirect methods to evaluate the reliability (accuracy) and reproducibility (precision) of the age estimates.

\section{Material And Methods}

Specimens of black scorpionfish (S. porcus) and small red scorpionfish ( $S$. notata) were collected in the northern Adriatic Sea between July 2004 and November 2008. The study area included both natural reefs/rocky outcrops and artificial structures such as artificial reefs located in coastal waters and offshore gas platforms (Fig. 1). Artificial reefs were located at about 1-6 km from the coast, at depths ranging from 8 to $15 \mathrm{~m}$. Offshore gas platforms were located at 36-52 $\mathrm{km}$ offshore on sandy or sandy-mud bottom, in 35 to $75 \mathrm{~m}$ depths. Natural reefs were located from the shoreline to around $100 \mathrm{~km}$ offshore.

Sampling was carried out in close proximity to both natural reefs and artificial structures using a beam trawl with $40 \mathrm{~mm}$ cod-end mesh size and trammel nets with a $70 \mathrm{~mm}$ stretched mesh size. Hauls performed with the beam trawl were randomly located over the whole sampling area. The beam trawl was generally towed at about $10 \mathrm{~km} \mathrm{~h}^{-1}$ for $15-30$ minutes during daylight. Trammel nets were set at dusk and pulled in at dawn, for a mean fishing time of $12 \mathrm{~h}$.

Each specimen caught was measured for Total Length (TL) to the nearest $\mathrm{mm}$ below. Both sagittal otoliths were removed from each fish, cleaned and stored dry in numbered vials. Length-frequency distributions of $S$. porcus and $S$. notata caught at natural reefs and artificial structures were compared with each other using the two-sample KolmogorovSmirnov test (SOKAL; ROHLF, 1995).

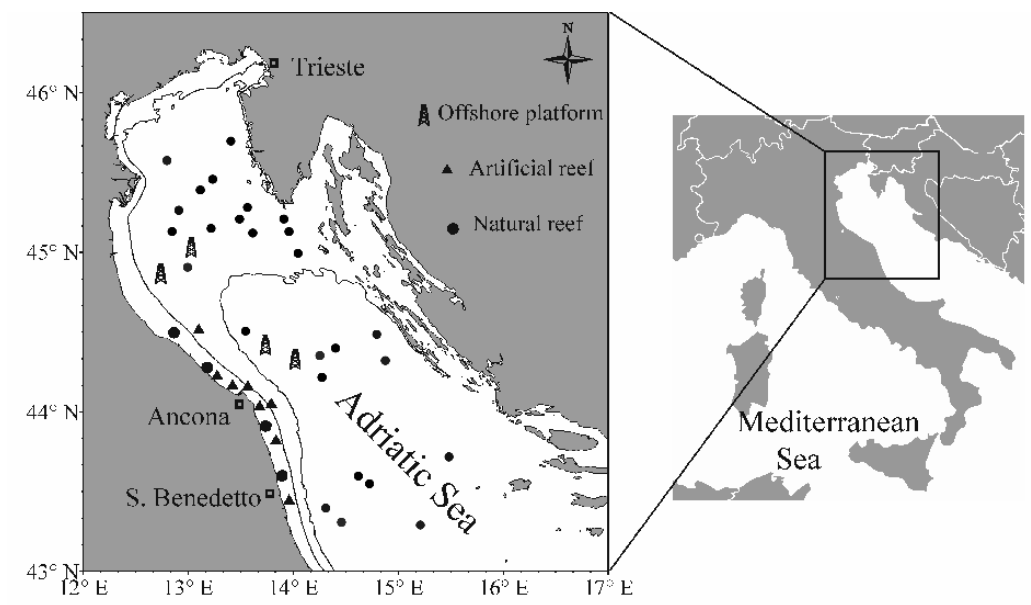

Fig. 1. Map of northern Adriatic Sea with the sampling stations where Scorpaena porcus and Scorpaena notata were caught. 
The otoliths were fully immersed in ethanol and observed under a stereomicroscope at 25-40x magnification. Under reflected light, the nucleus and the opaque zones appeared as light rings and the translucent or hyaline zones as dark rings (Fig. 2). This pattern was quite clear for $S$. porcus and also for the young specimens of $S$. notata, while the otoliths of larger specimens of $S$. notata required sectioning and grinding because the ring pattern was difficult to distinguish due to the considerable thickness of the otoliths. These otoliths were, therefore, embedded in epoxy resin and sectioned transversally. The otolith sections were then polished with $0.05 \mu \mathrm{m}$ alumina paste and read under reflected light following the same procedure as mentioned above (Fig. 3). To compare the readings of the two procedures as applied to otoliths of $S$. porcus and smaller specimens of $S$. notata, a representative sample of them was read directly as a whole and then sectioned. As the age estimates arrived at were the same, the sectioning practice was carried out only on the thick otoliths of larger (older) individuals of $S$. notata.

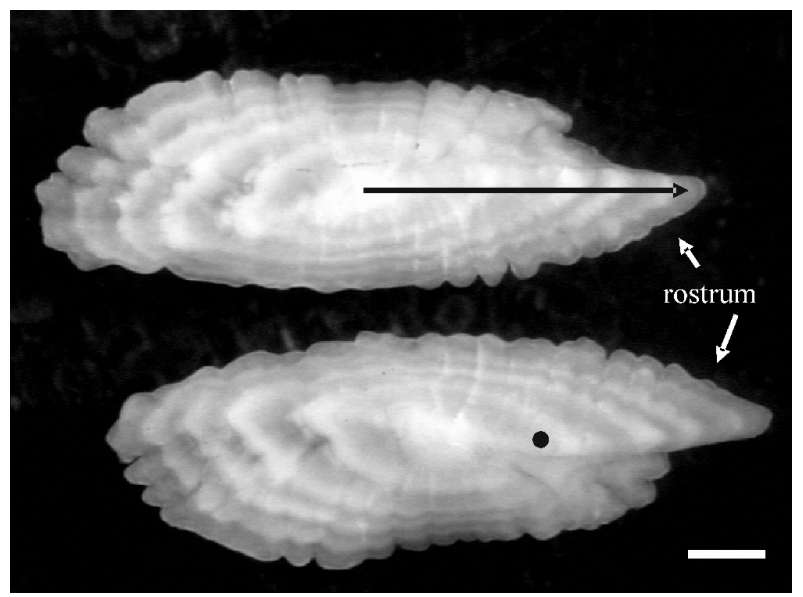

Fig. 2. Photomicrograph of the sagittal otolith of Scorpaena porcus, showing the annulation pattern in a five years old female. Scale bar $=1 \mathrm{~mm}$; first annulus (black dot); reading/measurement radius (black arrow).

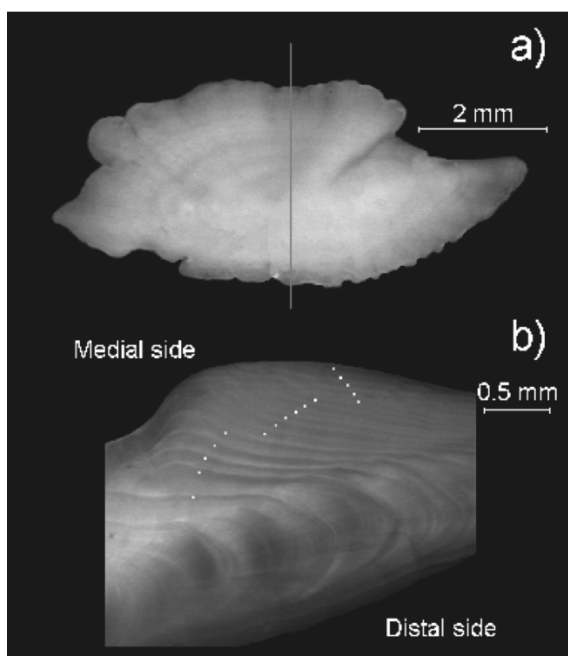

Fig. 3. Photographs of (a) surface and (b) crosssection otolith of Scorpaena notata, 16-yearsold female, $165 \mathrm{~mm}$ total length (TL). Vertical line indicate plane observed by cross-section. Dots denote annulus from 1st to 16th. 
The combination of each opaque and subsequent translucent zone was considered to form an annulus, as observed in other scorpaenids (MASSUTÍ et al., 2000; LÓPEZ ABELLÁN et al., 2001; LA MESA et al., 2005).

Each otolith was read by one reader, without any ancillary data on fish size. A second reading was carried out a week later by the same reader. When readings differed by one or more years, a third reading was made; if the difference persisted, the otolith was discarded. The index of Average Percentage Error (APE) (BEAMISH; FOURNIER, 1981) and the mean Coefficient of Variation (CV) (CHANG, 1982) were calculated to estimate the relative precision of the readings.

To validate the seasonality of deposition of opaque and translucent zones, marginal increment analysis was carried out on the entire otolith sample (SECOR et al., 1995; PANFILI et al., 2002). Since the spawning season of both species takes place between June and August (MUÑOZ et al., 2005), we considered 1st July as the birthdate of the species. We observed that the opaque nucleus was deposited during the first summer after hatching, followed by the first translucent zone laid down in the following winter just prior to the first birthday. Assuming that the annuli were added yearly, the age of the fish was estimated by counting all the translucent zones.

To validate specimens aged 0 years, i.e. fish with sagittae only composed of an opaque nucleus, some otoliths were prepared for the counting of microincrements, assuming they are laid down daily (LAIDIG; RALSTON, 1995; MASSUTÍ et al., 2000). The otoliths were set in moulds, embedded in epoxy resin and ground until the sagittal plane was reached. They were polished with $0.05 \mu \mathrm{m}$ alumina paste and

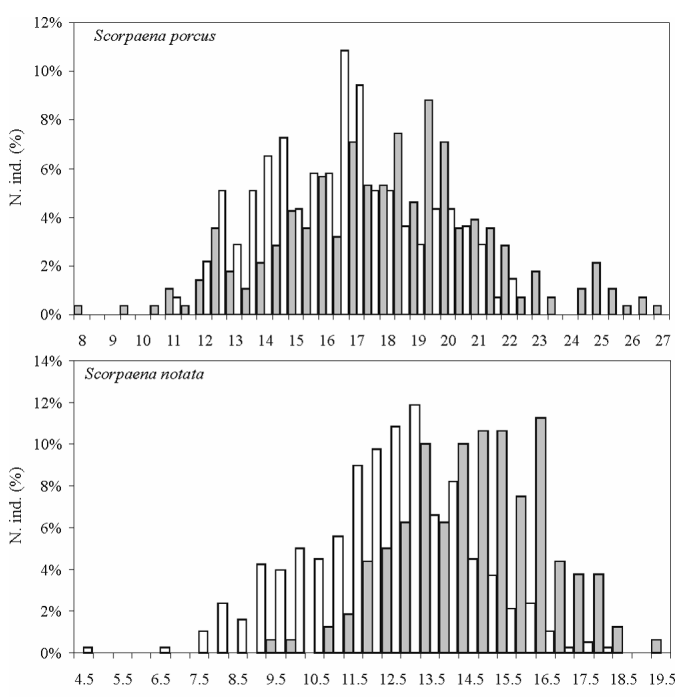

the micro-increments counted under a light microscope at $400 \times$ and $630 \times$ magnification.

The von Bertalanffy growth function was fitted to the estimated age-length data set taking into account the same size range and using the program FISHPARM of the statistical package FSAS (SAILA et al., 1988), applying the Marquardt algorithm for non-linear least square parameter estimation. The von Bertalanffy growth parameters $\left(\mathrm{L}_{\infty}, \mathrm{k}\right.$ and $\left.\mathrm{t}_{0}\right)$ were calculated for each population of each species sampled in natural reefs and artificial structures, respectively, and compared by the likelihood ratio test (KIMURA, 1980). A Student t test was employed to verify the differences between length-at-age data derived from the Von Bertalanffy growth curves.

\section{RESULTS}

Length Frequency Distributions

The length frequency distributions of $S$. porcus and $S$. notata populations caught on NR and AS are summarized in Fig. 4. As concerns the black scorpionfish, 138 specimens between 110-221 mm TL were caught on the NR, while 283 specimens between 80-270 mm TL were caught on AS. As regards the small red scorpionfish, 160 specimens between 47-180 mm TL were caught on the NR and 378 specimens between 95-199 $\mathrm{mm}$ TL on AS.

No comparison between length frequency distributions presented any statistical differences (Kolmogorov-Smirnov test $\mathrm{p}<0.01$ ). In particular, specimens of $S$. porcus and $S$. notata caught on AS were larger than those observed on NR (Fig. 4).
Fig. 4. Length frequency distributions of Scorpaena porcus and Scorpaena notata from natural reefs (white) and artificial structures (grey) in the northern Adriatic Sea. 
Age Estimates, Accuracy and Precision

The age composition estimated for each species caught on the NR and AS is summarized in the age-length keys (Tables 1 and 2). Age distributions and longevity were comparable as between the different populations of $S$. porcus and $S$. notata.

Table 1. Age-length keys of Scorpaena porcus from artificial structures and natural reefs in the northern Adriatic Sea

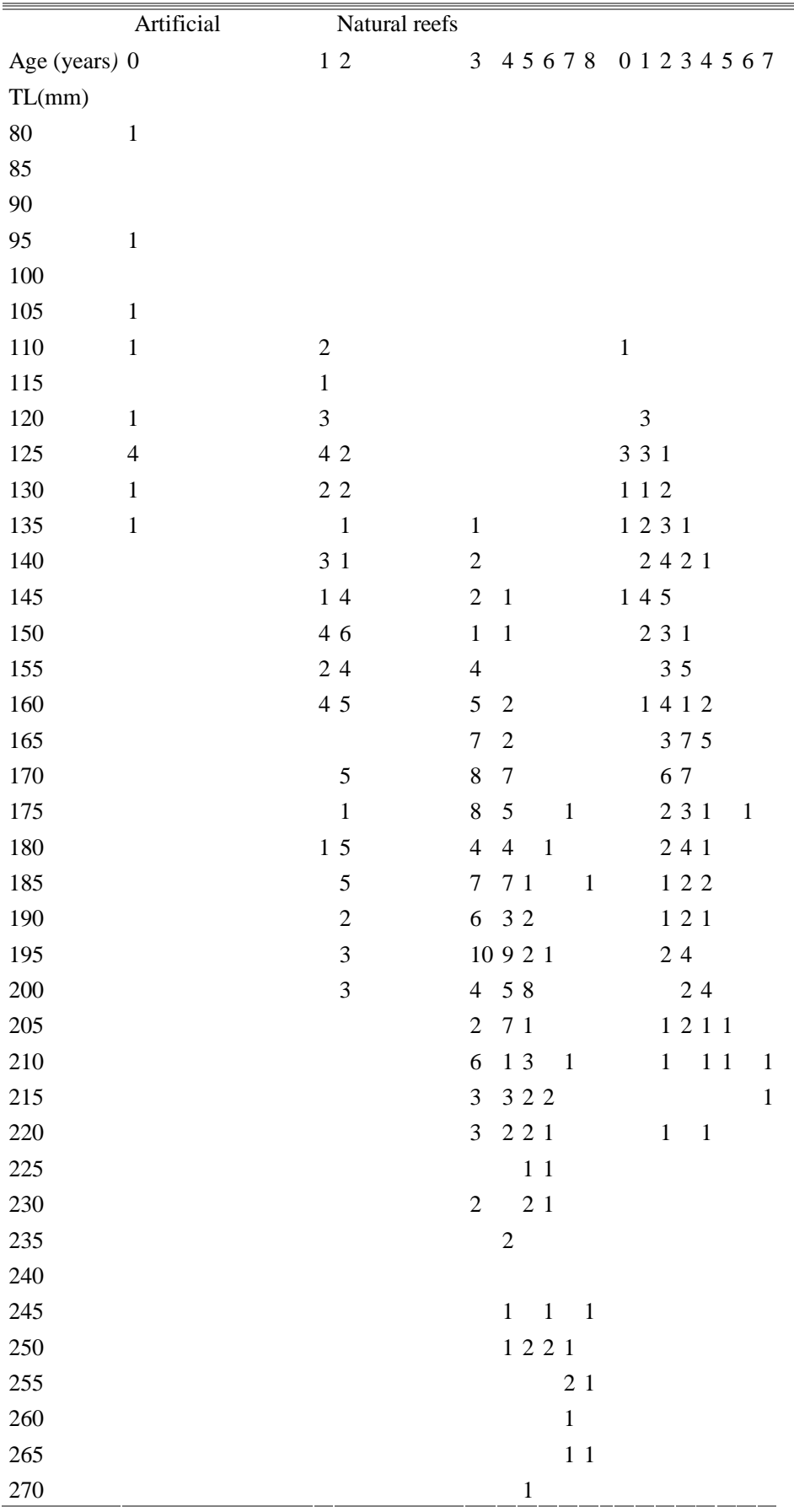


Table 2. Age-length keys of Scorpaena notata from artificial structures and natural reefs in the northern Adriatic Sea.

\begin{tabular}{|c|c|c|c|c|c|c|c|c|c|c|c|c|c|c|c|c|c|c|c|c|c|}
\hline & & $\begin{array}{l}\text { Artificial } \\
\text { structures }\end{array}$ & & $\begin{array}{c}\text { Natural } \\
\text { reefs }\end{array}$ & & & & & & & & & & & & & & & & & \\
\hline Age (years) & 1 & 1 & 2 & 3 & 4 & 567 & 89 & 101 & $11 \quad 12$ & 131 & 1416 & 01 & 2 & 3 & 456 & 6789 & 101 & 1112 & 13 & 1415 & 516 \\
\hline \multicolumn{22}{|l|}{$\mathrm{TL}(\mathrm{mm})$} \\
\hline 45 & & & & & & & & & & & & 1 & & & & & & & & & \\
\hline \multicolumn{22}{|l|}{50} \\
\hline \multicolumn{22}{|l|}{55} \\
\hline \multicolumn{22}{|l|}{60} \\
\hline 65 & & & & & & & & & & & & 1 & & & & & & & & & \\
\hline \multicolumn{22}{|l|}{70} \\
\hline 75 & & & & & & & & & & & & 22 & & & & & & & & & \\
\hline 80 & & & & & & & & & & & & 72 & & & & & & & & & \\
\hline 85 & & & & & & & & & & & & 24 & & & & & & & & & \\
\hline 90 & & & & & & & & & & & & 510 & 1 & & & & & & & & \\
\hline 95 & & 1 & & & & & & & & & & 212 & & 1 & & & & & & & \\
\hline 100 & & 1 & & & & & & & & & & 9 & 5 & 5 & & & & & & & \\
\hline 105 & & & & & & & & & & & & 7 & 6 & 4 & & & & & & & \\
\hline 110 & & 1 & 1 & & & & & & & & & 4 & 5 & 102 & & & & & & & \\
\hline 115 & & 1 & 2 & & & & & & & & & 8 & 8 & 13 & 4 & 1 & & & & & \\
\hline 120 & & & 4 & 2 & 1 & & & & & & & 4 & 11 & & 31 & 11 & & & & & \\
\hline 125 & & 1 & 6 & 1 & & & & & & & & 1 & 14 & $16^{7}$ & $\begin{array}{ll}7 & 1\end{array}$ & 11 & & & & & \\
\hline 130 & & 1 & 4 & 4 & 1 & & & & & & & & 12 & & 831 & 32 & 1 & 1 & & & \\
\hline 135 & & & 5 & 8 & 2 & 1 & & & & & & & 4 & 8 & $\begin{array}{ll}9 & 1\end{array}$ & 111 & & & & & \\
\hline 140 & & & 5 & 4 & 1 & & & & & & & & 1 & 11 & 812 & 232 & 21 & 1 & & & \\
\hline 145 & & & 3 & 9 & 1 & 111 & & & & & & & & 3 & 831 & & 2 & & & & \\
\hline 150 & & & 1 & 8 & 4 & 22 & & & & & & & & 3 & 6 & 211 & 1 & 1 & & & \\
\hline 155 & & & 2 & 6 & 3 & 1 & 2 & 11 & 1 & 1 & & & & 21 & 1 & 21 & & 1 & & 1 & \\
\hline 160 & & & 1 & 2 & 4 & 1 & 22 & & & & & & & & 11 & 2 & 2 & 1 & 1 & 1 & \\
\hline 165 & & & & 1 & 8 & 311 & & 2 & & 11 & & & & & 1 & 2 & 2 & & & & 1 \\
\hline 170 & & & & 1 & 1 & 1 & 11 & & & 1 & & & & & & & & & & 1 & \\
\hline 175 & & & & & 2 & 1 & 1 & & & & & & & & & 11 & & & & & \\
\hline 180 & & & & & 2 & & 11 & 1 & 11 & & & & & & & & & & 1 & & \\
\hline 185 & & & & & 1 & 1 & & & & & & & & & & & & & & & \\
\hline \multicolumn{22}{|l|}{190} \\
\hline 195 & & & & & & & & & & & 1 & & & & & & & & & & \\
\hline
\end{tabular}

The annual periodicity of annulus deposition was corroborated by the marginal increment analysis, indicating that each pair of translucent and opaque zones was formed over the course of a year. The opaque zone was deposited from February to August in $S$. porcus and from April to August in S. notata. For each species, the micro-increment counts to validate fish aged 0 years (i.e. young of the year) on the basis of the annuli were carried out on five specimens randomly selected from the sample of fish caught on the NR and the AS. The otolith microstructure showed the typical pattern of alternating light and dark increments, representing daily growth rings. A continuous series of concentric rings of increasing size ranging from 1.2 to $2.8 \mu \mathrm{m}$ in $S$. porcus and from 1.0 to $3.6 \mu \mathrm{m}$ in $S$. notata was observed from the core outward to the otolith margin. Age estimates were from 240 to 350 days for $S$. porcus and from 140 to 300 days for $S$. notata, thus validating specimens aged 0 years, namely those having sagittae with an opaque nucleus and a more or less developed translucent zone.

The reliability of the criteria used for judging the age of the two species was corroborated by the relatively high precision of the age readings. The count of the variability indices APE and CV was lower for $S$. notata (8.2 and $11.6 \%$, respectively), than for $S$. porcus $(9.8$ and $13.9 \%$, respectively), with a percentage agreement between readings of $56 \%$ for $S$. porcus and $62 \%$ for $S$. notata, indicating a reasonable consistency (or reproducibility) between readings. 
Growth Rate

In order to compare the growth rates of populations from different areas, the Von Bertalanffy parameters were computed and growth curves were fitted to age-length data pairs estimated for natural and artificial structures, with reference to the same size range (Fig. 5; Table 3). The likelihood ratio test indicated that for both species the overall Von Bertalanffy growth curves differed significantly between the two groups (NR and AS), as well as for $S$. notata alone when each parameter was considered separately (Table 4). No statistical differences in length-at-age data derived from the Von Bertalanffy growth curves (Table 5) were observed as between the two groups (NR and AS) of $S$. porcus (t-test for paired comparison, $\mathrm{df}=8, \mathrm{p}>0.5$ ), principally due to the similar growth patterns in the younger specimens. On the other hand, the comparison between the two groups (NR and AS; Table 5) was significant for $S$. notata ( $\mathrm{t}$-test for paired comparison, $\mathrm{df}=16, \mathrm{p}<0.05$ ).
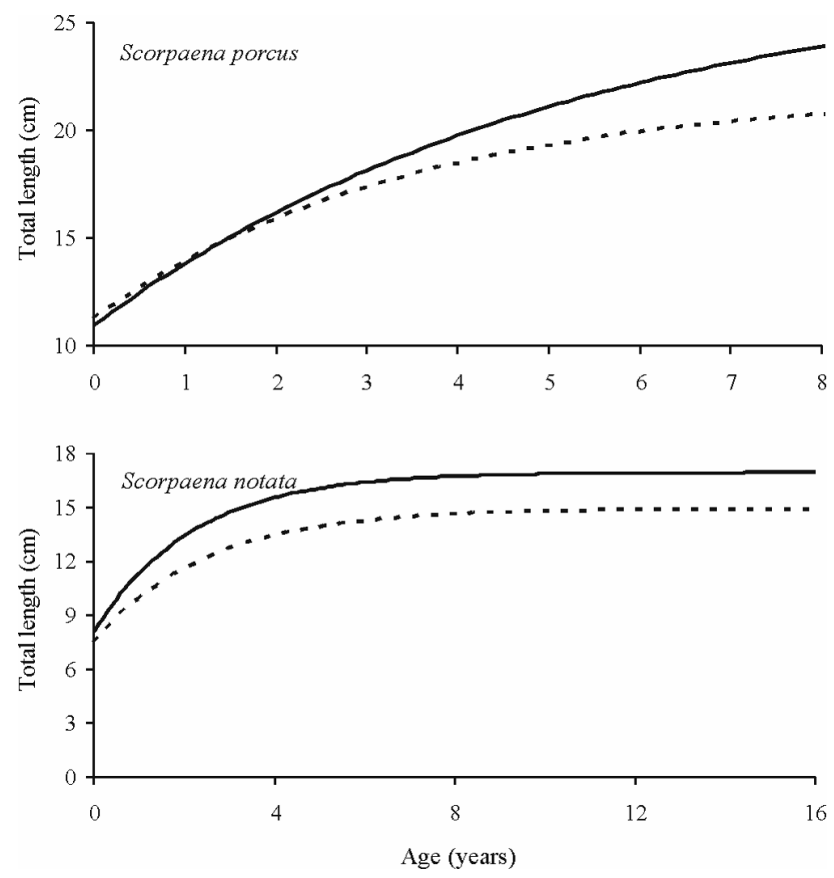

Fig. 5. Plot of Von Bertalanffy growth curves for natural reefs (dotted line) and artificial strucutres (solid line) populations of Scorpaena porcus and Scorpaena notata from the northern Adriatic Sea.

Table 3. Estimates of Von Bertalanffy growth parameters and growth performance of Scorpaena porcus and Scorpaena notata from artificial structures and natural reefs in the northern Adriatic Sea.

\begin{tabular}{|c|c|c|c|c|}
\hline \multicolumn{3}{|c|}{ Scorpaena porcus } & \multicolumn{2}{|c|}{ Scorpaena notata } \\
\hline & Artificial structures & $\begin{array}{c}\text { Natural } \\
\text { reefs }\end{array}$ & Artificial structures & $\begin{array}{c}\text { Natural } \\
\text { reefs }\end{array}$ \\
\hline $\mathrm{L}_{\infty}(\mathrm{cm})$ & 21.16 & 21.80 & 16.80 & 14.37 \\
\hline $\mathrm{k}\left(\right.$ year $\left.^{-1}\right)$ & 0.43 & 0.29 & 0.48 & 0.30 \\
\hline $\mathrm{t}_{0}($ year $)$ & -1.51 & -2.51 & -1.37 & -2.85 \\
\hline$\Phi^{\prime}$ & 2.29 & 2.14 & 2.13 & 1.84 \\
\hline$n$ & 255 & 138 & 159 & 341 \\
\hline
\end{tabular}

$n$, sample size. 
Table 4. Likelihood ratio test comparison of Von Bertalanffy parameters estimated for Scorpaena porcus and Scorpaena notata sampled from artificial structures (AS) and natural reefs (NR) in the northern Adriatic Sea.

\begin{tabular}{|c|c|c|c|c|c|}
\hline \multirow[b]{2}{*}{ Null hypothesis } & \multicolumn{3}{|c|}{ Scorpaena porcus } & \multicolumn{2}{|c|}{ Scorpaena notata } \\
\hline & d.f. & $\begin{array}{l}\text { Log residual } \\
\text { sum of } \\
\text { squares }\end{array}$ & $\chi^{2}$ & $\begin{array}{l}\text { Log residual } \\
\text { sum of } \\
\text { squares }\end{array}$ & $\chi^{2}$ \\
\hline $\mathrm{L}_{\infty \mathrm{AS}}=\mathrm{L}_{\infty \mathrm{NR}}$ & 1 & 1.277 & 0.258 & 23.577 & $0.001 * *$ \\
\hline $\mathrm{k}_{\mathrm{AS}}=\mathrm{k}_{\mathrm{NR}}$ & 1 & 6.873 & $0.032 *$ & 7.466 & $0.028^{*}$ \\
\hline $\mathrm{t}_{0 \mathrm{AS}}=\mathrm{t}_{0 \mathrm{NR}}$ & 1 & 0.078 & 0.781 & 8.337 & $0.011 *$ \\
\hline $\mathrm{L}_{\infty \mathrm{AS}}, \mathrm{k}_{\mathrm{AS}}, \mathrm{t}_{0 \mathrm{AS}}=\mathrm{L}_{\infty \mathrm{NR}}, \mathrm{k}_{\mathrm{NR}}, \mathrm{t}_{0 \mathrm{NR}}$ & 3 & 17.563 & $0.001 * *$ & 208.730 & $0.001 * *$ \\
\hline
\end{tabular}

d.f. $=$ degree of freedom; $*=$ significant at $\alpha=0.05 ; * *=$ significant at $\alpha=0.01$

Table 5. Estimated values of fish length-at-age of Scorpaena porcus and Scorpaena notata from artificial structures and natural reefs derived from the Von Bertalanffy equations in the northern Adriatic Sea.

\begin{tabular}{|c|c|c|c|c|}
\hline & \multicolumn{2}{|c|}{ Scorpaena porcus } & \multicolumn{2}{|c|}{ Scorpaena notata } \\
\hline & artificial structures & natural reefs & artificial structures & natural reefs \\
\hline Age & $\mathrm{TL}(\mathrm{cm})$ & $\mathrm{TL}(\mathrm{cm})$ & $\mathrm{TL}(\mathrm{cm})$ & $\mathrm{TL}(\mathrm{cm})$ \\
\hline 0 & 11.27 & 10.16 & 8.05 & 8.75 \\
\hline 1 & 13.92 & 14.02 & 11.36 & 10.44 \\
\hline 2 & 15.90 & 16.53 & 13.42 & 11.70 \\
\hline 3 & 17.39 & 18.15 & 14.70 & 12.64 \\
\hline 4 & 18.50 & 19.21 & 15.49 & 13.34 \\
\hline 5 & 19.33 & 19.89 & 15.99 & 13.86 \\
\hline 6 & 19.95 & 20.34 & 16.30 & 14.25 \\
\hline 7 & 20.42 & 20.63 & 16.49 & 14.53 \\
\hline 8 & 20.76 & 20.81 & 16.61 & 14.75 \\
\hline 9 & & & 16.68 & 14.91 \\
\hline 10 & & & 16.72 & 15.02 \\
\hline 11 & & & 16.75 & 15.11 \\
\hline 12 & & & 16.77 & 15.18 \\
\hline 13 & & & 16.78 & 15.23 \\
\hline 14 & & & 16.79 & 15.26 \\
\hline 15 & & & 16.79 & 15.29 \\
\hline 16 & & & 16.80 & 15.31 \\
\hline
\end{tabular}

\section{Conclusions}

The otoliths of the Scorpaenidae family are characterized by relatively large size (TUSET et al., 2008), making them easy to handle for the measurement of age. The inner structure of the sagittal otoliths of $S$. porcus and $S$. notata closely resembled those observed in other scorpaenids, with alternating patterns of translucent and opaque zones around an opaque nucleus. The seasonal trend of the formation of the opaque zone accompanied the pattern of sea bottom temperature closely (ARTEGIANI et al., 1997).
Consistent with findings related to many other scorpaenids, such as Helicolenus dactylopterus (MASSUTÍ et al., 2000), Scorpaena guttata (LOVE et al., 1987), Scorpaena maderensis (LA MESA et al., 2005) and Sebastes spp. (LOVE et al., 1990), the results of the present study showed that the annuli in the sagittal otoliths of $S$. porcus and $S$. notata are laid down annually, the opaque zone being generally deposited in spring-summer and the translucent zone in autumn-winter (MORALES-NIN, 2001). Moreover, the great consistency among repeated age readings makes otoliths the most reliable basis for ageing scorpaenid fish. 
Knowledge of the ecological behavior of fishes associated with artificial and natural habitats is very sketchy (CARR; HIXON, 1997). A pilot study has shown that young-of-the-year blue rockfish (genus Sebastes) grew faster at an offshore oil platform than on a natural outcrop, indicating that juvenile fishes at platforms are at least as healthy as those around natural outcrops (LOVE et al., 2007). Similarly, the present paper shows that the presence of artificial habitats in the northern Adriatic Sea affects growth rates and the growth indices of adults of S. notata and to a lesser extent of those of S. porcus positively. These results could play an important role in the ongoing attraction versus production debate (BRICKHILL et al., 2005)

As shown by the studies carried out in the central and northern Adriatic sea (BOMBACE et al., 1994; FABI et al., 2004), soon after the deployment of artificial reefs and gas platforms, fish abundance, species richness and diversity gradually increase, especially as a consequence of the increase of reefdwelling species (such as sciaenids and scorpaenids), which were very rare in the natural flat, soft bottom habitat. Artificial structures provide refuge and prey especially for those species, such as rockfish or scorpionfish, with cryptobenthic habits. The greater prey availability (mostly crustaceans and small fish) at these structures than in the natural open sea is probably one of the main factors affecting growth rates. This was more evident for $S$. notata, that displays more opportunistic trophic behavior than $S$. porcus (MORTE et al., 2001) and, hence, fully exploits the greater prey richness of artificial structures.

\section{REFERENCES}

ARTEGIANI, A.; BREGANT, D.; PASCHINI, E.; PINARDI, N.; RAICICH, F.; RUSSO, A. The Adriatic Sea general circulation. Part I: Air-sea interactions and water mass structure. J. Phys. Oceanogr., v. 27, p. 14921514, 1997.

BEAMISH, R. J.; FOURNIER D. A. A method of comparing the precision of a set of age determinations. Can. J. Fish. Aquat. Sci., v. 38, p. 982-983, 1981

BOMBACE, G.; FABI G.; FIORENTINI, L. Preliminary analysis of catch data from artificial reefs in Central Adriatic. FAO Fish. Rep., v. 428, p. 86-98, 1990

BOMBACE, G.; FABI, G.; FIORENTINI, L.; SPERANZA, S. Analysis of the efficacy of artificial reefs located in five different areas of the Adriatic Sea. Bull. mar. Sci., v. 55 , p. $528-538,1994$.

BOHNSACK, J. A.; SUTHERLAND, D.L. Artificial reef research: a review with recommendations for future priorities. Bull. mar. Sci., v. 37, n. 1, p. 11-39, 1985.

BRADAI, N.; BOUAIN, A. Age et croissance de Scorpaena porcus et Scorpaena scrofa du golfe de Gabes. Bull. Inst. Natn. Scient. Tech. Océanogr. Pêche Salammbô, v. 15, p. $13-38,1988$.
BRICKHILL, M. J.; LEE S. Y.; CONNOLLY, R. M. Fishes associated with artificial reefs: attributing changes to attraction or production using novel approaches. J. Fish Biol., v. 67, p. 53-71, 2005.

CARR, M. H.; HIXON, M. A. Artificial reefs: the importance of comparisons with natural reefs. Fisheries, v. 22, p. 28-33, 1997.

CASELLATO, S.; STEFANON, A. Coralligenous habitat in the northern Adriatic Sea: an overview. PSZN I: Mar. Ecol., v. 29, p. 321-341, 2008.

CHANG, W. Y. B. A statistical method for evaluating the reproducibility of age determination. Can. J. Fish. Aquat. Sci., v. 39, p. 1208-1210, 1982.

FABI, G.; FIORENTINI, L. Comparison between an artificial reef and a control site in the Adriatic Sea: analysis of four years of monitoring. Bull. Mar. Sci.,v. 53, p. 538558, 1994.

FABI, G.; GRATI, F.; PULETTI, M.; SCARCELLA, G. Effects on fish community induced by installation of two gas platforms in the Adriatic Sea. Mar. Ecol. Progr. Ser., v. 273, p. 187-197, 2004

FISCHER, W.; BAUCHOT, M. L.; SCHNEIDER, M. Fiches FAO d'identification des espèces pour les besoins de la pêche (Révision 1). Méditerranée et mer Noire. Zone de pêche 37, vol. 2, FAO, Rome. 1986. 1529 p.

JARDAS, I.; PALLAORO, A. Age and growth of black scorpionfish, Scorpaena porcus L., 1758 in the Adriatic Sea. Rapp. Comm. Int. Mer Médit., v. 33, p. 296, 1992.

JENSEN, A. Artificial reefs of Europe: perspective and future. . ICES J. mar. Sci., v.59 (Suppl), p. 3-13, 2002.

KIMURA, D. K. Likelihood methods for the von Bertalanffy growth curve. Fish. Bull., v. 77, p. 765-776, 1980.

LAIDIG, T. E.; RALSTON, S. The potential use of otolith characters in identifying larval rockfish (Sebastes spp.). Fish. Bull., v. 93, p. 166-171, 1995.

LA MESA, M.; LA MESA, G.; MICALIZZI, M. Age and growth of madeira scorpionfish, Scorpaena maderensis Valenciennes, 1833, in the central Mediterranean. Fish. Res., v. 74, p. 265-272, 2005.

LÓPEZ ABELLÁN, L. J.; SANTAMARÍA; M. T. G.; CONESA, P. Age and growth of Pontinus kuhlii (Bowdich 1825) in the Canary Islands. Sci. Mar., v. 65, p. 259-267, 2001.

LOVE, M. S.; AXELL, B.; MORRIS, P.; COLLINS, R.; BROOKS, R. Life history and fishery of the California scorpionfish, Scorpaena guttata, within the Southern California Bight. Fish. Bull., v. 85, p. 99-116, 1987.

LOVE, M. S.; MORRIS, P.; McCRAE, C; COLLINS, R. Life history aspects of 19 rockfish species (Scorpaenidae: Sebastes) from the Southern California Bight. NOAA Tech. Rep., v. 87, p. 1-38, 1990.

LOVE, M. S.; BROTHERS, E.; SCHROEDER, D. M.; LENARZ, W. H. Ecological performance of young-ofthe-year blue rockfish (Sebastes mystinus) associated with oil platforms and natural reefs in California as measured by daily growth rates. Bull. mar. Sci., v. 80, p. 147-157, 2007.

MASSUTÍ, E.; MORALES-NIN B.; MORANTA, J. Growth variability of blue-mouth Helicolenus dactylopterus (Osteichthyes: Scorpaenidae) in two western Mediterranean areas: Alboran Sea and Balearic Sea. Fish. Res., v. 46, p. 165-176, 2000. 
MORALES-NIN, B. Mediterranean deep-water fish age determination and age validation: the state of the art. Fish. Res., v. 51, p. 377-383, 2001

MORTE, S.; REDON, M. J.; SANZ-BRAU, A. Diet of Scorpaena porcus and Scorpaena notata (Pisces: Scorpaenidae) in the western Mediterranean. Cah. Biol. Mar., v. 42, p. 333-344, 2001.

MUÑOZ, M.; SABAT, M.; VILA, S.; CASADEVALL, M. Annual reproductive cycle and fecundity of Scorpaena notata (Teleostei : Scorpaenidae). Sci. Mar., v. 69, p. 555-562, 2005.

PAGE, H. M.; DUGAN, J. E.; DUGAN D. S.; RICHARDS J. B.; HUBBARD D. M. Effects of an offshore oil platform on the distribution and abundance of commercially important crab species. Mar. Ecol. Prog. Ser. v. 185, p. 47-57, 1999.

PANFILI, J.; DE PONTUAL, H.; TROADEC, D; WRIGHT, P. J. Manual of fish sclerochronology, IFREMER, France, 2002. 464 p.

SAILA, S.; RECKSIEK, C; PRAGER, M. Basic Fishery Science Programs. Amsterdam: Elsevier, 1988. 230 p.

SCARCELLA, G. Age and growth of Scorpaena porcus Linneus, 1758 and Scorpaena notata Rafinesque, 1810 in the northern Adriatic Sea. 2010. $126+$ XV p. Ph. D. Thesis - Università Politecnica delle Marche, Ancona, 2010 .
STANLEY, D. R.; WILSON, C. A. Variation in the density and species composition of fishes associated with three petroleum platforms using dual beam hydroacoustics. Fish. Res., v. 47, n. 2-3, p. 161-172, 2000.

SECOR, D. H.; DEAN, J. M; CAMPANA S. E. Recent developments in fish otolith research. Columbia: University of South Carolina Press, 1995. 725 p.

SOKAL, R. R.; ROHLF, F. J. Biometry. The principle and practice of statistics in biological research. San Francisco: WH Freeman, 1995. 401 p.

TUSET, V. M.; LOMBARTE, A.; ASSIS, C. A. Otolith atlas for the western Mediterranean, north and central eastern Atlantic. Sci. Mar., v. 72, suppl. 1, p. 7-198, 2008.

(Manuscript received 13 March 2010; revised 09 March 2011; accepted 15 March 2011) 